\title{
Whole-stream nitrate addition affects litter decomposition and associated fungi but not invertebrates
}

\author{
Verónica Ferreira • Vladislav Gulis • \\ Manuel A. S. Graça
}

Received: 28 October 2005 / Accepted: 27 May 2006 / Published online: 21 July 2006

(C) Springer-Verlag 2006

\begin{abstract}
We assessed the effect of whole-stream nitrate enrichment on decomposition of three substrates differing in nutrient quality (alder and oak leaves and balsa veneers) and associated fungi and invertebrates. During the 3-month nitrate enrichment of a headwater stream in central Portugal, litter was incubated in the reference site (mean $\mathrm{NO}_{3}-\mathrm{N} 82 \mu \mathrm{g} \mathrm{l}^{-1}$ ) and four enriched sites along the nitrate gradient (214-983 $\mu \mathrm{g} \quad \mathrm{NO}_{3}-\mathrm{N}^{-1}$ ). A similar decomposition experiment was also carried out in the same sites at ambient nutrient conditions the following year (33-104 $\mu \mathrm{g}$ $\mathrm{NO}_{3}-\mathrm{N}^{-1}$ ). Decomposition rates and sporulation of aquatic hyphomycetes associated with litter were determined in both experiments, whereas $\mathrm{N}$ and $\mathrm{P}$ content of litter, associated fungal biomass and invertebrates were followed only during the nitrate addition experiment. Nitrate enrichment stimulated decomposition of oak leaves and balsa veneers, fungal biomass accrual on alder leaves and balsa veneers and sporulation of aquatic hyphomycetes on all substrates. Nitrate concentration in stream water showed a strong asymp-
\end{abstract}

Communicated by Christian Körner

Electronic Supplementary Material Supplementary material is available to authorised users in the online version of this article at http://dx.doi.org/10.1007/s00442-006-0478-0.

\footnotetext{
V. Ferreira $(\bowtie) \cdot$ V. Gulis $\cdot$ M. A. S. Graça

Department of Zoology and Institute of Marine Research,

University of Coimbra, 3004-517 Coimbra, Portugal

e-mail: veronica@ci.uc.pt

Present Address:

V. Gulis

Department of Biological Sciences, University of Alabama,

Tuscaloosa, AL 35487, USA
}

totic relationship (Michaelis-Menten-type saturation model) with temperature-adjusted decomposition rates and percentage initial litter mass converted into aquatic hyphomycete conidia for all substrates. Fungal communities did not differ significantly among sites but some species showed substrate preferences. Nevertheless, certain species were sensitive to nitrogen concentration in water by increasing or decreasing their sporulation rate accordingly. $\mathrm{N}$ and $\mathrm{P}$ content of litter and abundances or richness of litter-associated invertebrates were not affected by nitrate addition. It appears that microbial nitrogen demands can be met at relatively low levels of dissolved nitrate, suggesting that even minor increases in nitrogen in streams due to, e.g., anthropogenic eutrophication may lead to significant shifts in microbial dynamics and ecosystem functioning.

Keywords Aquatic hyphomycetes - Leaves · Mass loss $\cdot$ Nitrogen $\cdot$ Wood

\section{Introduction}

The primary source of energy and carbon in small woodland streams is allochthonous organic matter provided by trees from the riparian zone (Fisher and Likens 1973; Vannote et al. 1980; Webster and Meyer 1997) mainly in the form of leaves and wood. Both microorganisms and shredding macroinvertebrates are important players in decomposition of this organic matter and their relative importance varies significantly among streams (e.g., Hieber and Gessner 2002 and references therein). Microbial decomposition in streams is primarily driven by aquatic fungi (Kaushik and Hynes 1971; Gessner and Chauvet 1994; Baldy 
et al. 1995) that incorporate leaf carbon into their mycelial biomass and conidia, mineralize it and also enhance leaf consumption by shredding invertebrates through leaf litter conditioning (Bärlocher and Kendrick 1981; Suberkropp 1992; Graça 2001). Since fungi can obtain nutrients from both the substrate and surrounding water (Suberkropp 1998), both litter quality (Gessner and Chauvet 1994; Royer and Minshall 2001; Díez et al. 2002; Stelzer et al. 2003) and nutrient concentrations in water (Suberkropp and Chauvet 1995; Niyogi et al. 2003; Pascoal et al. 2001, 2003) can affect their activity and hence plant litter decomposition.

Nutrient enrichment generally stimulates decomposition of plant litter in streams and associated microorganisms (e.g., Elwood et al. 1981; Grattan and Suberkropp 2001; Gulis and Suberkropp 2003) and the stimulation effect is more pronounced for low quality (i.e., low nutrients and high lignin) substrates (Stelzer et al. 2003; Gulis et al. 2004). However, in streams where a certain inorganic nutrient (i.e., $\mathrm{N}$ or $\mathrm{P}$ ) is not limiting, further increases in its concentration in water may not enhance litter decomposition or activity of associated microorganisms (Grattan and Suberkropp 2001; Royer and Minshall 2001). Furthermore, in case of organic pollution (e.g., sewage effluents), the oxygen concentration in water may drop significantly, which can lead to decreased activity, abundance and/or diversity of invertebrates and microbial decomposers, resulting in slower decomposition rates (Pascoal et al. 2001).

The numbers, diversity and biomass of invertebrates colonizing leaves have been related to nutrient concentration in stream water (Rosemond et al. 2002; Niyogi et al. 2003; Pascoal et al. 2003). The higher abundances of invertebrates associated with submerged leaf litter were reported in fertilized stream-side channels in comparison to the control (Pearson and Connolly 2000) and in fertilized versus control bags that corresponded to accelerated litter mass loss (Robinson and Gessner 2000). This could be a result of an increased fungal biomass associated with leaf litter (as reviewed by Graça 2001), but Robinson and Gessner (2000) did not report such increases.

Field studies assessing the effect of nutrients on litter decomposition and associated parameters have relied on comparisons of the reference unit(s) with (1) already existing high nutrient streams (Suberkropp and Chauvet 1995; Díez et al. 2002; Niyogi et al. 2003) or (2) experimentally enriched litter bags (Robinson and Gessner 2000; Royer and Minshall 2001), flow-through (Grattan and Suberkropp 2001) or stream-side channels (Pearson and Connolly 2000), whole streams (Elwood et al. 1981; Newbold et al. 1983; Gulis and Suberkropp 2003; Stelzer et al. 2003; Gulis et al. 2004) or catchments (Chadwick and Huryn 2003). A few studies dealt with decomposition and associated parameters along a nutrient gradient, within several streams (Suberkropp and Chauvet 1995; Rosemond et al. 2002; Niyogi et al. 2003) or within the same polluted river (Pascoal et al. 2003). However, different streams or reaches several kilometers apart may vary not only in nutrient content, but also in other physical, chemical or biological parameters.

In this study, we attempted to avoid such confounding effects by creating an experimental nitrate gradient within a short reach in an $\mathrm{N}$-limited, first-order forested stream in central Portugal and sampling at several sites within this reach (1-12 times ambient $\mathrm{N}$ concentration). We studied the effect of nitrate enrichment on decomposition of three substrate types differing in initial nutrient quality and on associated fungal and invertebrate parameters. Specifically, by creating a nitrate gradient we attempted to address the quantitative aspects of the response of decomposition and associated parameters to enrichment, such as the shape of the response curve or the existence of threshold or saturation phenomena within our nitrate concentration range.

\section{Materials and methods}

\section{Study site}

The study stream was located in the Margaraça Forest (Açor Mountains, Central Portugal, $40^{\circ} 13^{\prime} \mathrm{N}, 7^{\circ} 56^{\prime} \mathrm{W}$ ). The forest is a 50-ha protected area with NNW exposure, ca. $25^{\circ}$ slope and altitude ranging from 600 to $850 \mathrm{~m}$ a.s.l. The area has schistous soils and is covered by old growth deciduous forest composed mainly of Castanea sativa Miller, Quercus robur L., Arbutus unedo L. and Ilex aquifolium L. (Paiva 1981). The same trees dominated the riparian zone of our experimental first-order stream providing a closed canopy.

The experimental stream reach was ca. $270 \mathrm{~m}$ long, 0.7-2 $\mathrm{m}$ wide and had a maximum depth of about $10 \mathrm{~cm}$. It is a softwater, circumneutral stream with relatively low dissolved inorganic nitrogen concentration, but high soluble reactive phosphorus (SRP), which could be explained by underlying geology. Some physico-chemical parameters of the stream during our experiments are presented in Table 1 . We did not find any obvious trends in nutrient concentrations along our 270-m experimental reach during the decomposition experiment under ambient conditions or just before nitrate addition started (see below). For more information about the stream see Abelho and Graça (1998). 
Table 1 Physico-chemical characteristics of the study stream during decomposition experiments at ambient nutrient conditions and nitrate addition

\begin{tabular}{|c|c|c|}
\hline Parameter & $\begin{array}{l}\text { Ambient nutrients } \\
\text { experiment }\end{array}$ & $\begin{array}{l}\text { Nitrate addition } \\
\text { experiment }\end{array}$ \\
\hline Discharge $\left(1 \mathrm{~s}^{-1}\right)$ & $0.9(0.7-1.6)$ & $1.9(0.7-3.0)$ \\
\hline Temperature $\left({ }^{\circ} \mathrm{C}\right)$ & $7.9(2.8-13.6)$ & $9.6(7.5-11.7)$ \\
\hline Conductivity $\left(\mu \mathrm{S} \mathrm{cm}^{-1}\right)$ & $60(50-63)$ & $62(53-71)$ \\
\hline $\mathrm{PH}$ & $7.3(7.0-7.7)$ & 6.8 \\
\hline $\begin{array}{l}\text { Alkalinity } \\
\left(\mathrm{mg} \mathrm{CaCO}_{3} \mathrm{l}^{-1}\right)\end{array}$ & - & 31 \\
\hline $\operatorname{SRP}\left(\mu \mathrm{g} \mathrm{l}^{-1}\right)$ & $91(43-216)$ & $71(57-86)$ \\
\hline $\mathrm{NH}_{4}-\mathrm{N}\left(\mu \mathrm{g} \mathrm{l}^{-1}\right)$ & - & $<10$ \\
\hline $\mathrm{NO}_{3}-\mathrm{N}\left(\mu \mathrm{g} \mathrm{l}^{-1}\right)$ & $65(7-197)$ & $82(32-123)^{a}$ \\
\hline
\end{tabular}

Mean values are given with ranges in parentheses

${ }^{a}$ In the reference site

Nitrate gradient

The nitrate enrichment experiment was designed to: (1) achieve the target $\mathrm{NO}_{3}-\mathrm{N}$ concentration of $1,000 \mu \mathrm{g} \mathrm{l}^{-1}$ in the most enriched site (i.e., ca. 12 times the ambient concentration), (2) obtain a gradient of nitrogen concentration downstream from the addition point, and (3) achieve the nitrate concentration just above the ambient in the most downstream site. Continuous enrichment of stream water (9 October 2003-30 January 2004) was achieved by dripping concentrated filtered $\mathrm{NaNO}_{3}$ solution from a battery of five 5-1 glass Mariotte bottles. Bottles were refilled weekly and the dripping rate was corrected according to the instantaneous discharge (see below).

Litter bags (see below) were incubated in five sites (each 3-5 $\mathrm{m}$ long): the reference site just upstream from the addition point $(\mathrm{R})$ and four enriched sites downstream from the addition point, at 10 (N1), 100 $(\mathrm{N} 2), 220(\mathrm{~N} 3)$ and $255 \mathrm{~m}(\mathrm{~N} 4)$. We achieved a good contrast in nitrate concentrations among these relatively closely spaced stream sites (Fig. 1) because of presumably high biotic nitrate uptake and a dilution effect (discharge increased by ca. $40 \%$ from R to N4). In autumn 2004, litter bags were incubated at the same sites, but nutrients were not added (Fig. 1), and this decomposition experiment is further referred to as the "ambient nutrient conditions" experiment.

\section{Water parameters}

Water samples for nutrient analyses were taken weekly during the decomposition experiments. Water was filtered in the field through glass fiber filters (Millipore APFF), transported to the laboratory on ice and frozen until analyzed. Additional unfiltered water samples were taken during the nitrate addition only and

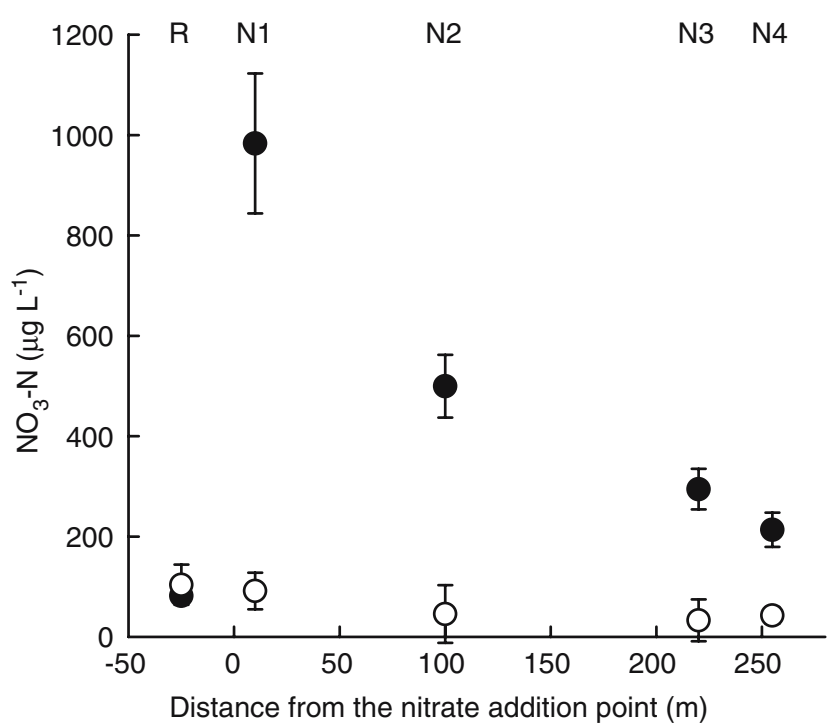

Fig. 1 Nitrogen concentration (mean \pm 1 SD) in stream water during decomposition experiments at ambient nutrient concentrations (open circle, $n=12$ ) and during the nitrate addition (filled circle, $n=9)$ in the reference $(R)$ and enriched $(N)$ sites

analyzed within $24 \mathrm{~h}$ for ammonium and alkalinity (APHA 1995). Nitrate and ammonium were determined by ion chromatography (Dionex DX-120, Sunnyvale, Calif., USA), SRP by the ascorbic acid method (APHA 1995) and alkalinity by titration to an end $\mathrm{pH}$ of 4.5 (APHA 1995).

Water temperature was continuously monitored at the reference site (both years) and additionally at N4 site during the nitrate addition experiment with Optic StowAway temperature probes (Onset Computer, Pocasset, Mass., USA) that recorded temperature every $30 \mathrm{~min}$. Stream water conductivity (WTW LF 330, Weilheim, Germany) and pH (JENWAY 3310, Essex, UK) were measured weekly. Stream discharge was determined weekly (to adjust the nitrate addition rate; see above) by short-term conservative tracer $(\mathrm{NaCl})$ release. Stream water conductivity was measured $10 \mathrm{~m}$ downstream from the release point after it reached the plateau in about 10-15 min, background conductivity was subtracted and discharge was calculated based on the increase in chloride concentration in water (Mulholland et al. 1994; Webster and Ehrman 1996).

Litter bags and decomposition

Three substrate types were used in our decomposition experiments: leaves of alder (Alnus glutinosa (L.) Gaertn.) and oak (Q. robur L.) in batches of 3.0-3.5 g per bag and balsa veneers (Ochroma pyramidale (Cav. ex Lam.) Urb.), two veneers $10 \times 7 \times 0.1 \mathrm{~cm}(1.8-4.6 \mathrm{~g})$ 
per bag. Leaves were collected in October-November 2003 , just after abscission, air-dried and stored until needed. Balsa veneers were purchased from a local supplier.

Substrates were deployed in the stream in coarse mesh bags $(10 \times 15 \mathrm{~cm}, 10 \mathrm{~mm}$ mesh size $)$ on 5 November 2003 (nitrate addition experiment) and on 17 October 2004 (ambient nutrient conditions experiment). Twenty bags of each substrate type were affixed to the streambed with nails at each experimental site. Four to six extra bags of each substrate type were taken to the stream and brought back to the laboratory the same day to determine initial ash free dry mass (AFDM, see below) and to take into account losses due to handling. Alder was sampled weekly over 5 weeks, oak and balsa at 2- to 3-week intervals over 12-15 weeks. At each sampling date, four replicate bags per substrate were retrieved from each site, placed in individual zip-lock bags and brought to the laboratory on ice for processing (within $24 \mathrm{~h}$ after collection). Each sample was gently rinsed with distilled water onto a $500-\mu \mathrm{m}$ mesh sieve to remove sediments and invertebrates (see below) and two sets of five disks each (12 mm diam.) were punched out with a cork borer for fungal biomass and sporulation rate determination (see below). The remaining material was dried at $105^{\circ} \mathrm{C}$ for $24-48 \mathrm{~h}$, weighed, ashed at $550^{\circ} \mathrm{C}$ for $4-6 \mathrm{~h}$ and reweighed to determine AFDM remaining.

Nitrogen and phosphorus in litter

On day 0 (alder, oak and balsa), 25 (alder), 55 (oak) and 86 (balsa) of the nitrate addition experiment, a subsample of leaf material or veneer was taken for nitrogen and phosphorus analyses. Nitrogen was extracted from $1.0-2.5 \mathrm{mg}$ of ground oven-dry material $\left(105^{\circ} \mathrm{C}, 24-48 \mathrm{~h}\right)$ by acid digestion $\left(96 \% \mathrm{H}_{2} \mathrm{SO}_{4}\right.$ plus $\mathrm{CuSO}_{4}$ ) on a hot plate (reduction to ammonia). The extract was neutralized, diluted, filtered and the absorbance was read at $630 \mathrm{~nm}$ after incubation with sodium nitroprussid and sodium hypochlorite reagents (Flindt and Lillebo 2005).

Phosphorus was extracted from $4-5 \mathrm{mg}$ of combusted leaf or wood material $\left(550^{\circ} \mathrm{C}, 4-6 \mathrm{~h}\right)$ by acid digestion $(37 \% \mathrm{HCl})$ on a hot plate. The extract was filtered, diluted and phosphorus was determined by the ascorbic acid method (Flindt and Lillebo 2005).

\section{Fungal biomass}

We attempted to collect samples during periods of peak fungal biomass according to our previous experience. Sets of five leaf or veneer disks collected on day
0, 18 (alder), 40 (oak) and 47 (balsa) of the nitrate addition experiment were used to estimate fungal biomass associated with decomposing litter from ergosterol concentration. The disks were stored in $10 \mathrm{ml}$ of $\mathrm{KOH}$ in methanol solution $\left(8 \mathrm{~g} \mathrm{l}^{-1}\right)$ at $-18^{\circ} \mathrm{C}$ until extraction. Lipid extraction and saponification was carried out at $80^{\circ} \mathrm{C}$ for $30 \mathrm{~min}$, with stirring. The extract was then purified by solid phase extraction (Gessner and Schmitt 1996; Gessner 2005). Ergosterol was quantified by high performance liquid chromatography (HPLC) by measuring absorbance at $282 \mathrm{~nm}$. HPLC system (Dionex, Sunnyvale, Calif., USA) was equipped with the Brownlee reverse phase $\mathrm{C}_{18}$ column (Applied Biosystems, Foster City, Calif., USA) maintained at $33^{\circ} \mathrm{C}$. The mobile phase was $100 \%$ methanol and the flow rate was set to $1.5 \mathrm{ml} \mathrm{min}^{-1}$. Ergosterol was converted into fungal biomass using a conversion factor of $5.5 \mathrm{mg}$ ergosterol $\mathrm{g}^{-1}$ fungal dry mass (Gessner and Chauvet 1993).

Aquatic hyphomycete sporulation

A set of five leaf or veneer disks was placed in 100-ml Erlenmeyer flasks containing $25 \mathrm{ml}$ of filtered (glass fiber filters, Millipore APFF) water from the corresponding stream site. Incubations were carried out on an orbital shaker $(100 \mathrm{rpm})$ for $48 \mathrm{~h}$ at $15^{\circ} \mathrm{C}$ to induce sporulation by aquatic hyphomycetes. The conidia suspensions were decanted in 50-ml centrifuge tubes, flasks rinsed twice, and conidia fixed with $2 \mathrm{ml}$ of $37 \%$ formalin to be counted and identified later. The corresponding disks were saved and their AFDM was determined as described above. When preparing slides for conidia identification, $100 \mu \mathrm{l}$ of $0.5 \%$ of Triton X-100 solution were added to the suspension to ensure a uniform distribution of conidia, stirred and an aliquot of the suspension was filtered (Millipore SMWP, $5 \mu \mathrm{m}$ pore size). Filters were stained with cotton blue in lactic acid $(0.05 \%)$ and spores were identified and counted with a compound microscope at 200 times.

\section{Macroinvertebrates}

Litter bag invertebrates were sampled only during the nutrient addition experiment. After rinsing each litter sample, invertebrates retained on sieve $(500 \mu \mathrm{m}$ mesh) were collected and stored in $70 \%$ ethanol. Identification was done to genus or species level when possible, except for Oligochaeta and some Diptera (family and subfamily or tribe, respectively), and for Hydracarina and Ostracoda (presence). The invertebrates were classified into two categories: shredders and nonshredders (Tachet et al. 2000). 
Data analysis

Decomposition rates, $k$, were calculated by linear regression of $\ln$ transformed data (negative exponential model $M_{t}=M_{\mathrm{o}} \cdot \mathrm{e}^{-k t}$, where $M_{\mathrm{o}}$ is the initial mass, $M_{t}$ is the remaining mass at time $t$ and $k$ is the decomposition rate). To account for rather small, but potentially important, differences in temperature between years, decomposition rates in degree days ${ }^{-1}$ were also calculated by replacing time $(t)$ by the sum of mean daily temperatures accumulated by the sampling day. To compare decomposition rates, we used ANCOVA followed by Tukey's test (Zar 1999). Relationships between nitrogen concentrations in water and decomposition rates were assessed by Michaelis-Menten-type saturation model (nonlinear curve fitting) and linear regression. Nitrogen and phosphorus content of plant litter and associated fungal biomass were compared among sites by ANOVA followed by Tukey's test.

Sporulation rates of aquatic hyphomycetes and invertebrate and shredder abundances were compared among sites by ANOVA with time as blocking variable followed by Tukey's test. The mass of conidia produced at each sampling date was estimated by multiplying sporulation rate of each species by specific mass of single conidium that were either published (Chauvet and Suberkropp 1998) or calculated from published biovolume data (Bärlocher and Schweizer 1983) and summing up. Cumulative conidial production by the end of decomposition experiments (in $\mathrm{mg}$ of conidial AFDM per mg of initial litter) was calculated by summing up values of daily production at each sampling date and linearly approximated values for each day between sampling dates. Conidial production data at each sampling date were resampled with replacement (1,000 times) to calculate and compare the percentage of initial litter mass converted into conidia at each stream site and estimate $95 \%$ confidence limits. The relationship between the nitrogen concentration in water and the percentage of litter converted into conidia was assessed by Michaelis-Menten-type saturation model. Multidimensional scaling (MDS) based on Bray-Curtis similarity matrix of mean abundances of aquatic hyphomycete conidia was performed for 75 samples $(5$ sites $\times 3$ substrate types $\times 5$ sampling dates) with Primer 6 software (Clarke and Gorley 2001). ANOSIM test was used to assess differences in aquatic hyphomycete communities among substrates and sites (Primer 6; Clarke and Gorley 2001). Relationships between nitrogen concentrations in water and mean abundances of aquatic hyphomycetes (based on spore production from both experiments) were assessed by Spearman rank correlation. Statistical analyses were done with SigmaStat 2 or Statistica 6 unless otherwise indicated.

\section{Results}

\section{Decomposition}

During the ambient nutrient conditions, we found that decomposition rates were generally similar to (alder) or even faster (oak and balsa) in the reference site than at most other sites (ANCOVA, Table 2). The relatively fast decomposition at site $\mathrm{N} 4$ during that season was probably caused by excessive mechanical abrasion during heavy rains due to suspended sediments in runoff from the unpaved road situated just upstream from site N4. In contrast, during the nitrate addition experiment, decomposition rates of oak at sites $\mathrm{N} 1$ and $\mathrm{N} 4$ and balsa veneers at N2, N3 and N4 were significantly higher than those in the reference site (ANCOVA followed by Tukey's test, $P=0.003$ for oak and $P<0.001$ for balsa, Table 2). Decomposition rates for alder were similar among the experimental sites during the nitrate addition (ANCOVA, $P=0.121$ ). There was no significant interaction (ANCOVA, $P=0.310$ ) between the effects of substrate and nitrate (site) while both variables (ANCOVA, $P<0.001$ ) had significant effects on decomposition rates during the nitrate addition.

Temperature corrected decomposition rates (degree days $^{-1}$ ) of alder leaves were similar between years for all sites except N4 (see above). Decomposition was not significantly different in the reference site between years for oak and balsa, while it was significantly faster during nitrate addition at sites $\mathrm{N} 1$ for oak and $\mathrm{N} 2$ and N3 for balsa (ANCOVA, $P<0.001$ ), suggesting that the observed differences are the result of our manipulation and not intrinsic differences among sites.

When decomposition data (degree days ${ }^{-1}$ ) from both years (except N4 data at ambient conditions, see above) were considered, the relationship between nitrate concentration in water and decomposition rate of all substrates was best explained by MichaelisMenten-type saturation model (Fig. 2). Linear regressions of $\log 10(\mathrm{NO} 3-\mathrm{N})$ versus decomposition rates were also significant for all substrates even though this simple model lacks theoretical basis.

\section{Nitrogen and phosphorus in litter}

Nitrogen content of alder leaves at day 25 (2.7-3.4\%), oak leaves at day $55(1.5-2.1 \%)$ and balsa veneers at day $86(1.2-1.5 \%)$ was generally higher than initial 
Table 2 Decomposition rates $(k)$ of alder and oak leaves and balsa veneers incubated in the reference (R) and nitrogen enriched (N) sites during decomposition experiments at ambient conditions and nitrate addition

\begin{tabular}{|c|c|c|c|c|c|c|c|c|c|c|}
\hline & \multirow{2}{*}{$\begin{array}{l}\text { Stream } \\
\text { Site }\end{array}$} & \multicolumn{3}{|l|}{ Alder } & \multicolumn{3}{|l|}{ Oak } & \multicolumn{3}{|l|}{ Balsa } \\
\hline & & $\begin{array}{l}k\left(\text { day }^{-1}\right) \pm 95 \% \\
\mathrm{CL}\end{array}$ & $R^{2}$ & & $\begin{array}{l}k\left(\text { day }^{-1}\right) \pm 95 \% \\
\text { CL }\end{array}$ & $R^{2}$ & & $\begin{array}{l}k\left(\text { day }^{-1}\right) \pm 95 \% \\
\mathrm{CL}\end{array}$ & $R^{2}$ & \\
\hline \multirow[t]{5}{*}{ Ambient conditions } & $\mathrm{R}$ & $0.0309 \pm 0.0076$ & 0.57 & $\mathrm{a}$ & $0.0091 \pm 0.0005$ & 0.95 & $\mathrm{~b}$ & $0.0077 \pm 0.0011$ & 0.80 & $\mathrm{c}$ \\
\hline & $\mathrm{N} 1$ & $0.0294 \pm 0.0042$ & 0.65 & $\mathrm{a}$ & $0.0079 \pm 0.0005$ & 0.93 & $a b$ & $0.0073 \pm 0.0013$ & 0.75 & $\mathrm{c}$ \\
\hline & $\mathrm{N} 2$ & $0.0180 \pm 0.0019$ & 0.78 & $\mathrm{a}$ & $0.0059 \pm 0.0002$ & 0.97 & $\mathrm{a}$ & $0.0045 \pm 0.0008$ & 0.72 & $\mathrm{~b}$ \\
\hline & N3 & $0.0298 \pm 0.0057$ & 0.57 & $\mathrm{a}$ & $0.0070 \pm 0.0008$ & 0.83 & $a b$ & $0.0021 \pm 0.0004$ & 0.63 & $\mathrm{a}$ \\
\hline & N4 & $0.0725 \pm 0.0101$ & 0.82 & $\mathrm{~b}$ & $0.0136 \pm 0.0015$ & 0.78 & $\mathrm{c}$ & $0.0077 \pm 0.0009$ & 0.84 & $\mathrm{c}$ \\
\hline \multirow[t]{5}{*}{ Nitrate addition } & $\mathrm{R}$ & $0.0319 \pm 0.0040$ & 0.61 & $\mathrm{a}$ & $0.0103 \pm 0.0010$ & 0.87 & $\mathrm{a}$ & $0.0064 \pm 0.0008$ & 0.84 & $\mathrm{a}$ \\
\hline & N1 & $0.0416 \pm 0.0065$ & 0.56 & $\mathrm{a}$ & $0.0146 \pm 0.0023$ & 0.76 & $\mathrm{c}$ & $0.0088 \pm 0.0009$ & 0.85 & $\mathrm{a}$ \\
\hline & $\mathrm{N} 2$ & $0.0328 \pm 0.0031$ & 0.83 & $\mathrm{a}$ & $0.0099 \pm 0.0008$ & 0.88 & $\mathrm{a}$ & $0.0098 \pm 0.0007$ & 0.94 & $\mathrm{~b}$ \\
\hline & N3 & $0.0363 \pm 0.0063$ & 0.57 & $\mathrm{a}$ & $0.0116 \pm 0.0011$ & 0.88 & $a b$ & $0.0095 \pm 0.0008$ & 0.91 & $\mathrm{~b}$ \\
\hline & N4 & $0.0410 \pm 0.0059$ & 0.69 & $\mathrm{a}$ & $0.0139 \pm 0.0029$ & 0.62 & $\mathrm{bc}$ & $0.0104 \pm 0.0008$ & 0.92 & $\mathrm{~b}$ \\
\hline
\end{tabular}

$95 \%$ confidence limits are included. Comparisons were made among sites for each substrate type and experiment separately [ANCOVA followed by Tukey's test, different letters indicate significant differences $(P<0.05)$ among slopes]

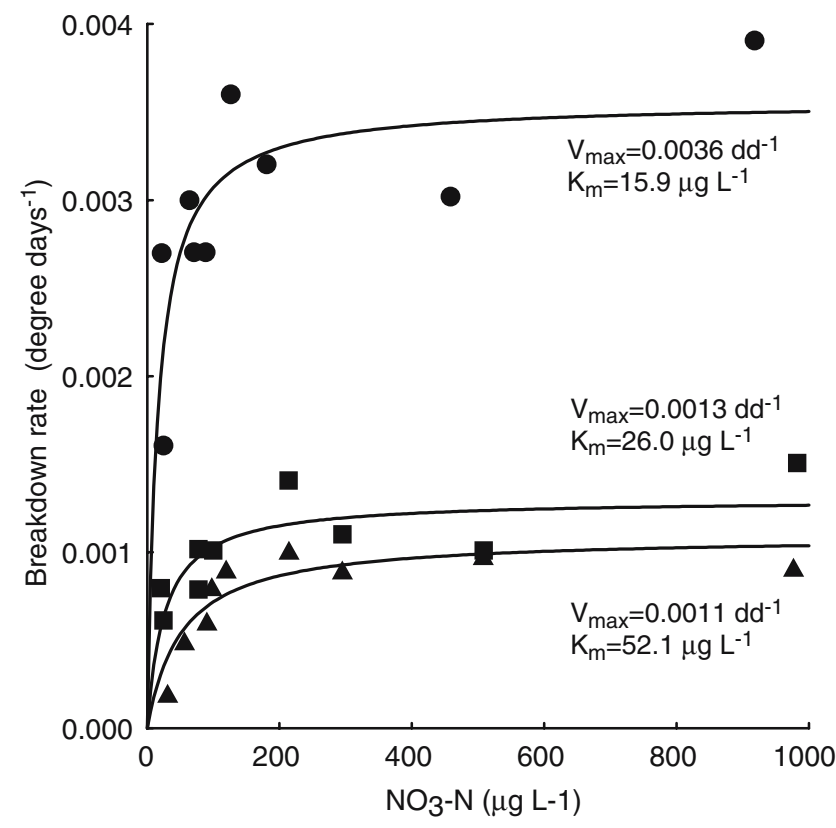

Fig. 2 Relationship between the nitrate concentration in stream water and decomposition rates of alder (filled circle) and oak (filled square) leaves and balsa veneers (filled triangle) during decomposition experiments at both ambient nutrient conditions and during nitrate addition. Data are fit into Michaelis-Mententype model $V=\left(V_{\max } \cdot[S]\right) /\left(K_{\mathrm{m}}+[S]\right)$, where $V_{\max }$ is the maximum decomposition rate, $K_{\mathrm{m}}$ is the nitrate concentration at which half rate of decomposition is achieved, $[S]$ is nitrate concentration. The model gave $R^{2}$ of $0.53,0.58$ and 0.78 for alder, oak and balsa, respectively, and $P<0.0001$ for all substrates

content (2.5, 1.0 and $0.3 \%$, respectively; Fig. 3), suggesting microbial $\mathrm{N}$ immobilization at least for veneers. The highest nitrogen values associated with oak and balsa veneers were found in the site $\mathrm{N} 2$ while no differences among sites were detected for alder leaves.
Phosphorus content of alder leaves $(0.11-0.14 \%)$ and balsa veneers $(0.13-0.16 \%)$ increased in comparison to the initial levels $(0.09$ and $0.01 \%$, respectively), with a trend for higher values at the most $\mathrm{N}$ enriched sites (Fig. 3). Phosphorus content of oak leaves was similar across all sites $(0.10-0.11 \%)$ and did not increase in comparison to the initial level $(0.11 \%$; ANOVA, $P>0.05$; Fig. 3). No significant relationships were found between nitrogen or phosphorus content of all three substrates and nitrogen concentration in water during the nitrate addition experiment (linear regressions, $P>0.05$ ).

Fungal biomass

Fungal biomass associated with alder leaves at day 18 was significantly higher in the nitrate enriched sites (114-132 $\mathrm{mg} \mathrm{g}^{-1}$ AFDM) than in the reference site (67 $\mathrm{mg} \mathrm{g}^{-1}$ AFDM; ANOVA, $P<0.01$, Fig. 3), except for site N3 (91 $\mathrm{mg} \mathrm{g}^{-1}$ AFDM; ANOVA, $P>0.05$ ). No significant difference among sites in fungal biomass associated with oak leaves at day 40 was found (117$134 \mathrm{mg} \mathrm{g}^{-1}$ AFDM; ANOVA, $\left.P>0.05\right)$. Fungal biomass associated with balsa veneers at day 47 was significantly higher at all nitrate-enriched sites (136$177 \mathrm{mg} \mathrm{g}^{-1}$ AFDM) than in the reference site (69 $\mathrm{mg} \mathrm{g}^{-1}$ AFDM; ANOVA, $P<0.001$ ). No significant relationships were found between fungal biomass associated with all three substrates and nitrogen concentration in water during the nitrate addition experiment (linear regressions, $P>0.05$ ).

Sporulation of aquatic hyphomycetes

Under ambient nutrient conditions sporulation rates of aquatic hyphomycetes were similar among all sites for 
Fig. 3 Nitrogen and phosphorus content, fungal biomass associ- $\rightarrow$ ated with alder and oak leaves and balsa veneers (mean $\pm 1 \mathrm{SE}$ ) and percentage of initial plant litter AFDM converted into conidia of aquatic hyphomycetes (mean $\pm 95 \%$ CL) in the reference $(R)$ and nitrogen enriched $(N)$ sites during nitrate addition experiment. Initial values $(I)$ for $\mathrm{N}$ and $\mathrm{P}$ content and fungal biomass are also given. Different letters indicate significant differences $(P<0.05)$ among sites (ANOVA followed by Tukey's test). \% N and $\% \mathrm{P}$ were measured on day 25,55 and 86 , fungal biomass on day 18,40 and 47 , and percentage of initial leaf litter converted into conidia is given by day 33,85 and 86 of the nutrient addition experiment for alder, oak and balsa veneers, respectively

oak (ANOVA, $P=0.68$ ), but for alder and balsa, sites $\mathrm{N} 2$ and N3, respectively, differed from all other sites (ANOVA followed by Tukey's test, $P<0.02$ ). During the nitrate enrichment, sporulation rates of aquatic hyphomycetes were higher in sites N1-N3 (alder), N1$\mathrm{N} 2$ (oak) and all enriched sites (balsa) than in the reference site (ANOVA, Tukey's test, $P<0.02$; Fig. 4). However, no differences in conidial production among the enriched sites (with the only exception of N2 and N4 for balsa veneers) were found.

The percentage of initial alder and oak leaf litter and balsa wood converted into conidia by the end of experiment was higher in the enriched sites in comparison to the reference site in all instances during the nitrate addition experiment (Fig. 3). The relationship between nitrate concentration in water and percentage of initial litter AFDM converted into conidia was well described by Michaelis-Menten-type saturation model (Fig. 5).

A total of 23 species of aquatic hyphomycetes were identified in this study (Table S1). We did not find apparent differences in total species richness among experiments or sites. Tetrachaetum elegans (mean relative abundance $43-83 \%$ ) dominated fungal communities associated with alder leaves in all sites during the ambient conditions experiment. Lemonniera aquatica $(30 \%)$ and Lemonniera terrestris (29\%) assumed dominance in the reference site, while T. elegans (31-60\%) and Articulospora tetracladia (18-29\%) dominated on alder in the enriched sites during nitrate addition experiment. On oak leaves, T. elegans dominated in all sites during both experiments (35-79\%). Fungal community associated with balsa veneers was quite different from those of leaf litter. Anguillospora crassa (27-64\%) followed by Clavariopsis aquatica (17-50\%) dominated on wood in all sites during the ambient conditions experiment and in the reference site during the nitrate addition. Their ranks switched (45-62\% for $C$. aquatica and $17-34 \%$ for $A$. crassa) in the enriched sites during the nitrate addition experiment.

MDS ordination (Fig. 6) grouped samples by substrate type and not by stream site for both experiments
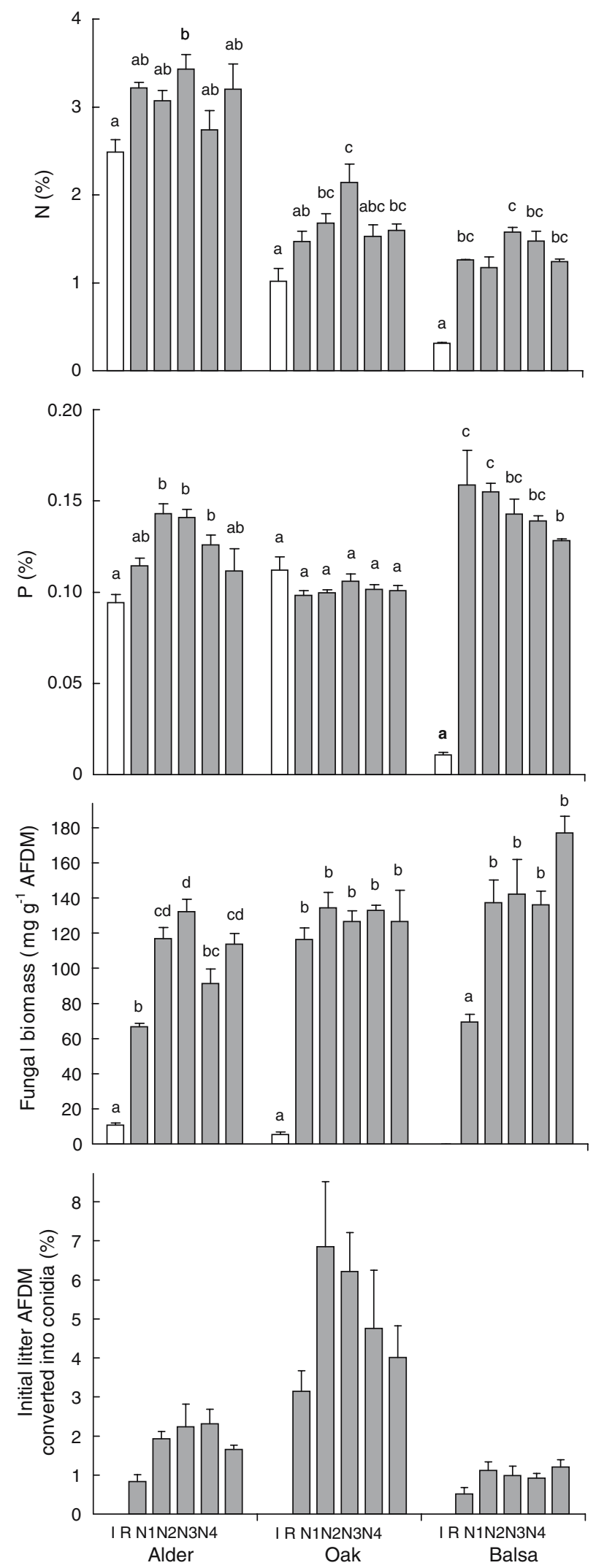

(ANOSIM, $P=0.001$ and $R=0.72$ for substrate type and $P=0.03$ and $R=0.07$ for sites during ambient nutrient conditions; $P=0.001$ and $R=0.63$ for substrate type and 

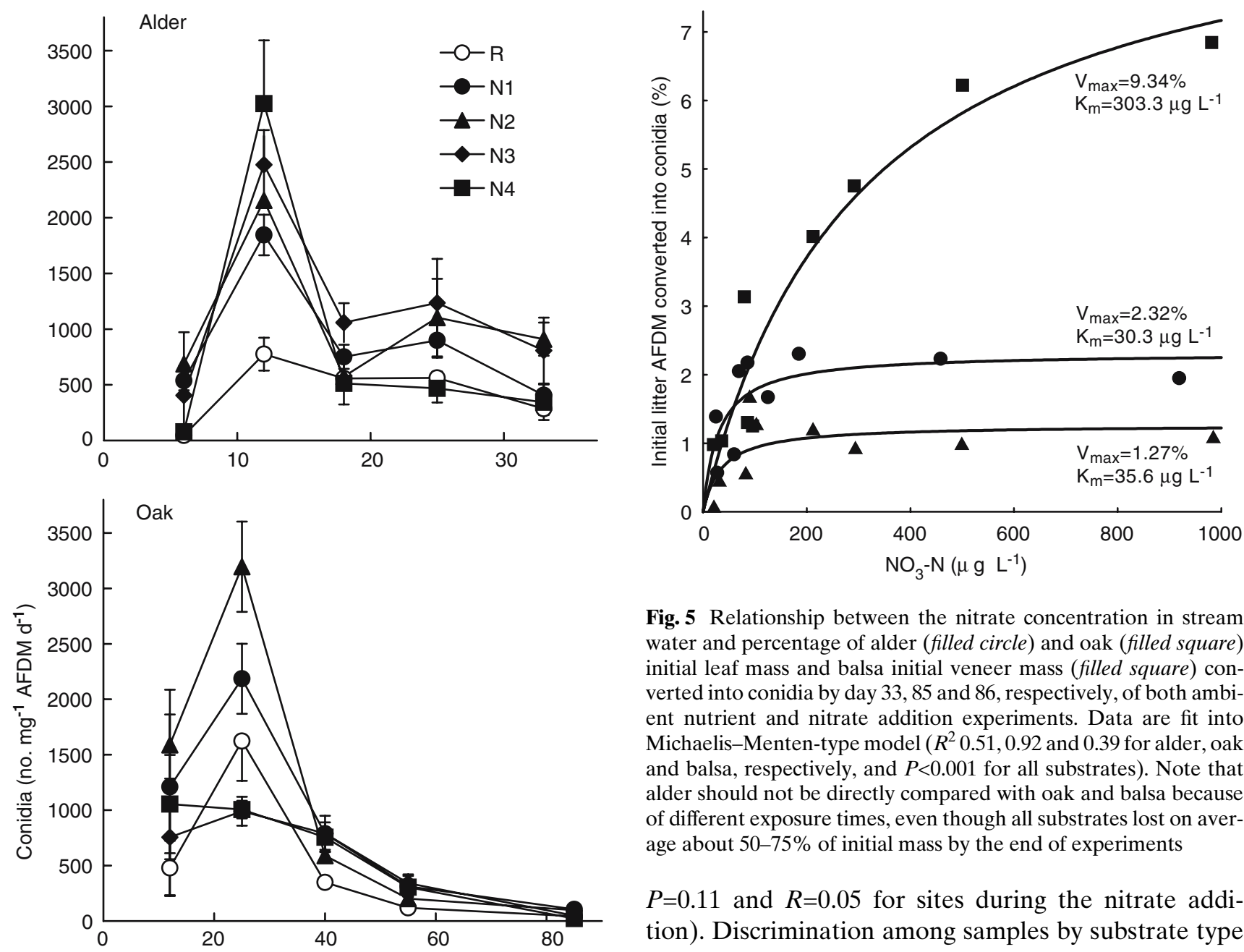

Fig. 5 Relationship between the nitrate concentration in stream water and percentage of alder (filled circle) and oak (filled square) initial leaf mass and balsa initial veneer mass (filled square) converted into conidia by day 33,85 and 86 , respectively, of both ambient nutrient and nitrate addition experiments. Data are fit into Michaelis-Menten-type model $\left(R^{2} 0.51,0.92\right.$ and 0.39 for alder, oak and balsa, respectively, and $P<0.001$ for all substrates). Note that alder should not be directly compared with oak and balsa because of different exposure times, even though all substrates lost on average about $50-75 \%$ of initial mass by the end of experiments

$P=0.11$ and $R=0.05$ for sites during the nitrate addition). Discrimination among samples by substrate type was mainly due to presence or absence of some species on a certain substrate; e.g. A. tetracladia, Flagellospora curvula and $T$. elegans occurred almost exclusively on leaves while $A$. crassa and $C$. aquatica preferred wood veneers (Table S1). Overall, the fungal community data was not useful in discriminating stream sites even when each substrate was considered separate. However, a few species were sensitive to nitrogen concentration in water and changed their sporulation rates accordingly. For example, A. tetracladia (on alder leaves), and $T$. elegans (oak) increased their conidia production with increased nitrogen concentration in water (Spearman rank correlation, $P<0.05$ ) while Alatospora acuminata (oak) had lower sporulation rates in nutrient enriched sites (Spearman rank correlation, $P<0.05$ ) (Table S1).

\section{Macroinvertebrates}

Fig. 4 Sporulation rate of aquatic hyphomycetes associated with alder and oak leaves and balsa veneers in the reference $(R)$ and nitrogen enriched $(N)$ sites during nitrate enrichment experiment. Vertical bars indicate $\pm 1 \mathrm{SE}$

Abundance of invertebrates colonizing litter bags during the nitrate addition reached peaks of 28,128 and 21 

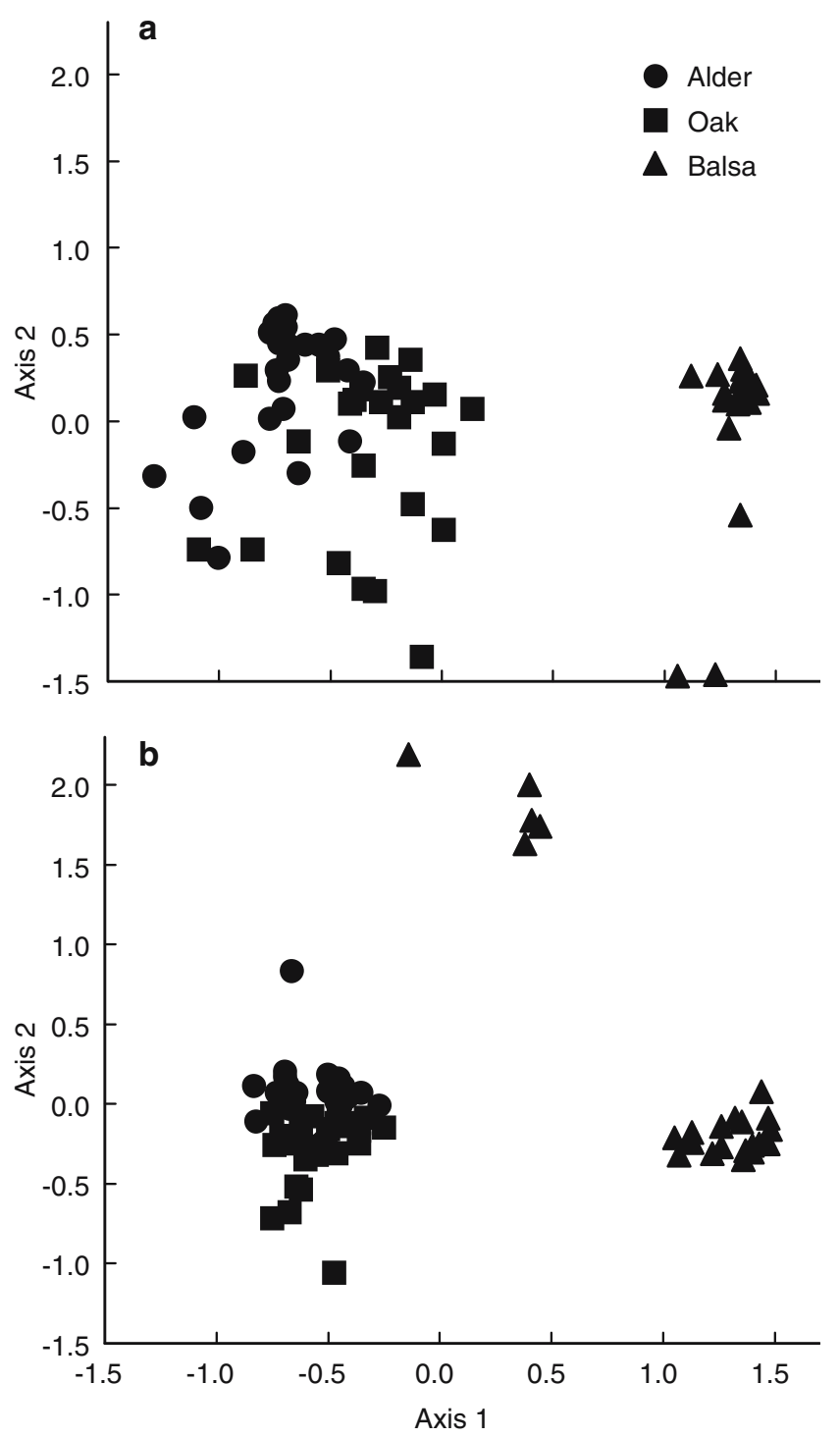

Fig. 6 Ordination (MDS) of all samples $(5$ sites $\times 3$ substrate types $\times 5$ sampling dates) based on aquatic hyphomycete conidia abundances during decomposition experiments at both ambient nutrient concentrations (a) and nitrate addition (b)

individuals $\mathrm{g}^{-1}$ AFDM for alder, oak and balsa, respectively (data not shown). Shredders represented 4-96\% of the total invertebrates. Overall, shredder abundance was low, typically less than five individuals $\mathrm{g}^{-1}$ AFDM. No significant differences were found among sites for all three substrates for either total invertebrate or shredder abundances (ANOVA, $P>0.27$ ).

\section{Discussion}

Decomposition of plant litter and associated microbial activity and invertebrate colonization depend on both substrate qualities and a suite of stream characteristics.
The design of this study compares favorably with many correlative studies where the effects in question can be confounded by uncontrolled variability of other parameters. During the nitrate enrichment, decomposition rates of oak (but not alder) leaves and balsa veneers were generally higher than those under ambient nutrient conditions, and the slowest decomposition was found in the reference site, suggesting that the observed differences were caused by the nitrate addition and not intrinsic differences among sites. Such stimulation of litter decomposition by increased nitrogen concentration in water has been shown by Elwood et al. (1981) for ammonium in an enrichment experiment and by Nikolcheva and Bärlocher (2005) for nitrate in correlative study, but was not found by Grattan and Suberkropp (2001) in a nitrate enrichment study. Overall, decomposition rates of alder leaves in our experiment were comparable to those reported in previous studies for the Iberian Peninsula (Pozo et al. 1998; Pascoal et al. 2001, 2003, 2005), while oak showed faster decomposition than previously reported (Molinero et al. 1996). Decomposition of balsa veneers has not been previously studied in aquatic systems. It had relatively high decomposition rates in our experiments probably due, in part, to high surface to volume ratio and low density. However, decomposition rates were lower than those reported by Gulis et al. (2004) for oak veneers in a nutrient enriched stream.

We found no obvious trends in decomposition rates between sites N1-N4 during the nitrate addition, suggesting that factors other than nitrate (e.g., mechanical fragmentation, invertebrate feeding, etc.) considerably affected decomposition rates at each particular site. Nevertheless, when $k$-values from both experiments were pooled, significant relationships with nitrogen concentrations in water were found for all substrates (Fig. 2). Michaelis-Menten-type saturation model better explained our experimental data than linear regression of $\log$ transformed nitrate concentration versus decomposition, even though both models were significant. Apparent nutrient saturation occurred at relatively low nitrate concentrations (half saturation constant $K_{\mathrm{m}}$ was less than $52 \mu \mathrm{g} \mathrm{NO}_{3}-\mathrm{N}^{-1}$ for all substrates), suggesting that even slight increases in nitrate concentration in water may lead to significant changes in decomposition rates. It is not surprising that decomposition of balsa veneers (low quality, low nutrient substrate) was the most nitrate limited (highest $K_{\mathrm{m}}$ ), while decomposition of alder (high $\mathrm{N}$ substrate) was the least nitrate limited (lowest $K_{\mathrm{m}}$ ). The magnitude of the response to nutrient enrichment has previously been shown to be driven in part by substrate $\mathrm{C}: \mathrm{N}$ ratio (Stelzer et al. 2003; Gulis et al. 2004). 
The absence of consistent differences in nitrogen and phosphorus content of all substrates among sites suggests that nutrient immobilization did not increase with higher nitrate concentration in water. The opposite was observed by Gulis and Suberkropp (2003) and Gulis et al. (2004) in a stream enriched by both N and P. Fungal biomass associated with alder leaves and balsa veneers during the nitrate addition was significantly higher in the enriched sites than in the reference site. It is surprising that we did not observe similar response for oak litter, especially in view of clearcut sporulation results (see below). Since fungal biomass often increases to a maximum and then declines, we may have missed the ergosterol peak on oak litter because leaves from only one sampling date were analyzed. Experimental enrichment of stream water with nitrate has been reported to increase fungal biomass associated with yellow poplar litter (Grattan and Suberkropp 2001) but no effect has been found for two species of leaves and five types of wood in another experiment (Stelzer et al. 2003). In the latter case, fungi were probably $\mathrm{P}$ limited due to extremely low ambient SRP of stream water and, hence, $\mathrm{N}$ addition alone did not stimulate fungi. Our stream, in contrast, had high natural $P$ availability.

During our nitrate enrichment experiment, sporulation rates of aquatic hyphomycetes were stimulated at the most enriched sites, which is in agreement with previous correlative studies (Suberkropp and Chauvet 1995; Nikolcheva and Bärlocher 2005), enrichment experiment (Grattan and Suberkropp 2001) and laboratory studies (e.g., Suberkropp 1998; Sridhar and Bärlocher 2000). In our study, the percentage of initial litter AFDM converted into conidia was also higher in the enriched sites than in the reference site for all substrates. Surprisingly, the extent to which cumulative conidial output was stimulated was similar among substrates. The ratio of the percentage of initial litter AFDM converted into conidia by the time of $60-70 \%$ mass loss between the reference and the most enriched site (N1) for all substrates ranged between 2.2 and 2.3 This disagrees with the previous report of stronger stimulation of fungal sporulation by nutrient enrichment on lower quality than on high quality substrates (Gulis and Suberkropp 2003). We also found strong asymptotic relationship between the nitrate concentration in water and efficiency of converting organic substrate into conidia (Fig. 5). Huryn et al. (2002) also applied the Michaelis-Menten-type model to describe the relationship between nitrate in stream water and rate of leaf litter softening (penetrometry), which is thought to reflect microbial activity (Suberkropp et al. 1983). The $K_{\mathrm{m}}$ values from our study are about an order of magnitude higher than those reported by Huryn et al. (2002), though they are not directly comparable because of different parameters measured and much higher SRP concentration in our stream that probably led to higher biotic $\mathrm{N}$ demand. Nevertheless, our $K_{\mathrm{m}}$ estimates are still relatively low to suggest that sporulation of aquatic hyphomycetes is quite sensitive to nitrate concentration in water and even low levels of eutrophication may cause profound changes in fungal activity and hence plant litter decomposition. The similarity between this saturation-type relationship for conidia production and the relationship between the nitrate concentration in water and litter decomposition rates (Fig. 2) suggests that aquatic hyphomycetes are indeed major players in litter decomposition in streams (e.g., Gessner and Chauvet 1994).

Only 23 species of aquatic hyphomycetes were identified from decaying litter in this study while 42 species were recorded from water samples from the same stream by Bärlocher and Graça (2002; the stream is referred to as Margaraça 1 there). The difference in sampling technique and the fact that samples were collected over 12-month period in their study versus only 3 months in autumn in our study could explain the difference in species richness. Overall, the fungal community data were not useful in discriminating among sites even though some fungal species were sensitive to nitrate concentration in water and increased or decreased their contribution to the total spore production (Table S1). Similar sensitivity of certain fungal species to inorganic nutrients in water was reported by Gulis and Suberkropp (2003) and Pascoal et al. (2005). In our study, fungal communities were discriminated rather by the substrate type since some species showed clear preference toward either leaves or wood. The fungal assemblages colonizing balsa veneers were different from those colonizing leaves as they had lower number of species that were present in a different proportion in comparison to what was observed on leaves that led to a good separation in MDS analysis (Fig. 6). Surprisingly, even the two leaf species were differentiated to some degree based on their fungal assemblages. The differences between fungal communities colonizing leaves versus wood were previously reported by Gulis (2001) based on conidia occurrences while Nikolcheva and Bärlocher (2005) did not find a strong effect of the substrate (including wood) on fungal communities using both traditional and molecular techniques.

Our nitrate enrichment did not affect total invertebrate or shredder abundances. This could be explained by the relatively short duration of nitrate exposure (13 months depending on the substrate). Apparently, at 
the concentration used, nitrate did not directly affect invertebrates causing drift or appreciable migration to or from the impacted sites. Cross et al. (2005) found that long-term $\mathrm{N}$ and $\mathrm{P}$ enrichment of a headwater stream resulted in increased invertebrate abundances and production that was probably mediated by stimulated microbial activity. Our experiment was too short to notice such an increase. Nevertheless, some studies (Pearson and Connolly 2000; Robinson and Gessner 2000) reported increased invertebrate abundance associated with decaying leaves after a few months of fertilization.

Overall, nitrate enrichment of stream water appeared to stimulate plant litter decomposition, biomass and sporulation rate of aquatic hyphomycetes, which is in line with observations from correlative studies by Suberkropp and Chauvet (1995) and Nikolcheva and Bärlocher (2005). In our experiment, the response of fungi and, consequently, decomposition rate to nitrate was best described by the Michaelis-Mententype saturation model, suggesting that responses to nutrient enrichment depend on absolute level of nutrient availability in streams. It appears that microbial nitrogen demands can be met at relatively low levels of nitrate (one or two orders of magnitude lower than can be encountered in polluted streams) that suggests that even minor increases in dissolved nitrogen in streams due to, e.g., anthropogenic eutrophication may lead to significant shifts in microbial dynamics and ecosystem functioning.

Acknowledgments We thank Aranzazu Marcotegui for help with ergosterol extractions, Elsa Rodrigues for ion chromatography and HPLC analyses and Nuno Coimbra and Andreia Ferreira for field assistance. Michael Chadwick is thanked for advise and help with bootstrapping conidial production data. We are grateful to Keller Suberkropp and two anonymous reviewers for their comments on an earlier draft of the manuscript. We also thank ICN-Paisagem Protegida da Serra do Açor for allowing us to conduct the experiments in the Margaraça forest. This study was supported through the EU project "RivFunction" (EVKI2001-00088). Financial support by the Fundação para a Ciência e Tecnologia (Programa POCTI/SFRH/BD/11350/2002) to V.F. is gratefully acknowledged. The experiments reported here comply with the current laws of Portugal.

\section{References}

Abelho M, Graça MAS (1998) Litter in a first-order stream of a temperate deciduous forest (Margaraça Forest, central Portugal). Hydrobiologia 386:147-152

American Public Health Association (1995) In: Eaton AE, Clesceri LS, Greenberg AE (eds) Standard methods for the examination of water and wastewater, 19th edn. Washington DC

Baldy V, Gessner MO, Chauvet E (1995) Bacteria, fungi and breakdown of leaf litter in a large river. Oikos 74:93-102
Bärlocher F, Graça MAS (2002) Exotic riparian vegetation lowers fungal diversity but not leaf decomposition in Portuguese streams. Freshw Biol 47:1123-1135

Bärlocher F, Kendrick B (1981) Role of aquatic hyphomycetes in the trophic structure of streams. In: Wicklow DT, Carroll GC (eds) The fungal community: its organization and role in the ecosystem. Marcel Dekker, New York, pp 743-760

Bärlocher F, Schweizer M (1983) Effects of leaf size and decay rate on colonization by aquatic hyphomycetes. Oikos 41:205-210

Chadwick MA, Huryn AD (2003) Effect of a whole-catchment N addition on stream detritus processing. J N Am Benthol Soc 22:194-206

Chauvet E, Suberkropp K (1998) Temperature and sporulation of aquatic hyphomycetes. Appl Environ Microbiol 64:15221525

Clarke KR, Gorley RN (2001) Primer v5: user manual/tutorial. Primer-E, Plymouth

Cross WF, Johnson BR, Wallace JB, Rosemond AD (2005) Contrasting response of stream detritivores to long-term nutrient enrichment. Limnol Oceanogr 50:1730-1739

Díez J, Elosegi A, Chauvet E, Pozo J (2002) Breakdown of wood in the Agüera stream. Freshw Biol 47:2205-2215

Elwood JW, Newbold JD, Trimble AF, Stark RW (1981) The limiting role of phosphorus in a woodland stream ecosystem: effects of $\mathrm{P}$ enrichment on leaf decomposition and primary producers. Ecology 62:146-158

Fisher SG, Likens GE (1973) Energy flow in Bear Brook, New Hampshire: an integrative approach to stream ecosystem metabolism. Ecol Monogr 43:421-439

Flindt MR, Lillebo AI (2005) Determination of total nitrogen and phosphorus in leaf litter. In: Graça MAS, Bärlocher F, Gessner MO (eds) Methods to study litter decomposition: a practical guide. Springer, The Netherlands, pp 53-59

Gessner MO (2005) Ergosterol as a measure of fungal biomass. In: Graça MAS, Bärlocher F, Gessner MO (eds) Methods to study litter decomposition: a practical guide. Springer, The Netherlands, pp 189-195

Gessner MO, Chauvet E (1993) Ergosterol-to-biomass conversion factors for aquatic hyphomycetes. Appl Environ Microbiol 59:502-507

Gessner MO, Chauvet E (1994) Importance of stream microfungi in controlling breakdown rates of leaf litter. Ecology 75:1807-1817

Gessner MO, Schmitt AL (1996) Use of solid-phase extraction to determine ergosterol concentrations in plant tissue colonized by fungi. Appl Environ Microbiol 62:415-419

Graça MAS (2001) The role of invertebrates on leaf litter decomposition in streams: a review. Int Rev Hydrobiol 86:383-393

Grattan RM, Suberkropp K (2001) Effects of nutrient enrichment on yellow poplar leaf decomposition and fungal activity in streams. J N Am Benthol Soc 20:33-43

Gulis V (2001) Are there any substrate preferences in aquatic hyphomycetes? Mycol Res 105:1088-1093

Gulis V, Suberkropp K (2003) Leaf litter decomposition and microbial activity in nutrient-enriched and unaltered reaches of a headwater stream. Freshw Biol 48:123-134

Gulis V, Rosemond AD, Suberkropp K, Weyers HS, Benstead JP (2004) The effect of nutrient enrichment on the decomposition of wood and associated microbial activity in streams. Freshw Biol 49:1437-1447

Hieber M, Gessner MO (2002) Contribution of stream detritivores, fungi, and bacteria to leaf breakdown based on biomass estimates. Ecology 83:1026-1038

Huryn AD, Huryn VM, Arbuckle CJ, Tsomides L (2002) Catchment land-use, macroinvertebrates and detritus processing 
in headwater streams: taxonomic richness versus function. Freshw Biol 47:401-415

Kaushik NK, Hynes HBN (1971) The fate of dead leaves that fall into streams. Arch Hydrobiol 68:465-515

Molinero J, Pozo J, Gonzáles E (1996) Litter breakdown in streams of the Agüera catchment: influence of dissolved nutrients and land use. Freshw Biol 36:745-756

Mulholland PJ, Steinman AD, Marzolf ER, Hart DR, DeAngelis DL (1994) Effect of periphyton biomass on hydraulic characteristics and nutrient cycling in streams. Oecologia 98:40-47

Newbold JD, Elwood JW, Schulze MS, Stark RW, Barmeier JC (1983) Continuous ammonium enrichment of a woodland stream: uptake kinetics, leaf decomposition and nitrification. Freshw Biol 13:193-204

Nikolcheva LG, Bärlocher F (2005) Seasonal and substrate preferences of fungi colonizing leaves in streams: traditional versus molecular evidence. Environ Microbiol 7:270-280

Niyogi DK, Simon KS, Townsend CR (2003) Breakdown of tussock grass in streams along a gradient of agricultural development in New Zealand. Freshw Biol 48:1698-1708

Paiva JAR (1981) Mata da Margaraça e sua conversão em reserva. Ann Soc Brot 47:49-66

Pascoal C, Cássio F, Gomes P (2001) Leaf breakdown rates: a measure of water quality? Int Rev Hydrobiol 86:407-416

Pascoal C, Pinho M, Cássio F, Gomes P (2003) Assessing structural and functional ecosystem condition using leaf breakdown: studies in a polluted river. Freshw Biol 48:2033-2044

Pascoal C, Cássio F, Marvanová L (2005) Anthropogenic stress may affect aquatic hyphomycete diversity more than leaf decomposition in a low-order stream. Arch Hydrobiol 162:481-496

Pearson RG, Connolly NM (2000) Nutrient enhancement, food quality and community dynamics in a tropical rainforest stream. Freshw Biol 43:31-42

Pozo J, Basaguren A, Elósegui A, Molinero J, Fabre E, Chauvet E (1998) Afforestation with Eucalyptus globulus and leaf litter decomposition in streams of northern Spain. Hydrobiologia 373/374:101-109

Robinson CT, Gessner MO (2000) Nutrient addition accelerates leaf breakdown in an alpine springbrook. Oecologia 122:258-263
Rosemond AD, Pringle CM, Ramírez A, Paul MJ, Meyer JL (2002) Landscape variation in phosphorus concentration and effects on detritus-based tropical streams. Limnol Oceanogr 47:278-289

Royer TV, Minshall W (2001) Effects of nutrient enrichment and leaf quality on the breakdown of leaves in a hardwater stream. Freshw Biol 46:603-610

Sridhar KR, Bärlocher F (2000) Initial colonization, nutrient supply, and fungal activity on leaves decaying in streams. Appl Environ Microbiol 66:1114-1119

Stelzer RS, Heffernan J, Likens GE (2003) The influence of dissolved nutrients and particulate organic matter quality on microbial respiration and biomass in a forest stream. Freshw Biol 48:1925-1937

Suberkropp K (1992) Interactions with invertebrates. In: Bärlocher F (eds) The ecology of aquatic hyphomycetes. Springer, Berlin Heidelberg New York, pp 118-134

Suberkropp K (1998) Effect of dissolved nutrients on two aquatic hyphomycetes growing on leaf litter. Mycol Res 102:9981002

Suberkropp K, Chauvet E (1995) Regulation of leaf breakdown by fungi in streams: influences of water chemistry. Ecology 76:1433-1445

Suberkropp K, Arsuffi TL, Anderson JP (1983) Comparison of degradative ability, enzymatic activity, and palatability of aquatic hyphomycetes grown on leaf litter. Appl Environ Microbiol 46:237-244

Tachet H, Richoux P, Bournaud M, Usseglio-Polatera F (2000) Invertébrés d'eau douce. Systématique, biologie, écologie. CNRS Editions, Paris

Vannote RL, Minshall GW, Cummins KW, Sedell JR, Cushing CE (1980) The river continuum concept. Can J Fish Aquat Sci 37:130-137

Webster JR, Ehrman TP (1996) Solute dynamics. In: Hauer FR, Lamberti GA (eds) Methods in stream ecology. Academic, San Diego, pp 145-160

Webster JR, Meyer JL (1997) Stream organic matter budgets. J N Am Benthol Soc 16:3-161

Zar JH (1999) Biostatistical analysis, 4th edn. Prentice-Hall, Englewood Cliffs 